\title{
NATO Before and After the Second Gulf War
}

\section{Mustafa Kibaroglu*}

For an assessment of the possible roles NATO may have in the future, and their possible implications for international security, it would be useful to look back in order to make a meaningful assessment of where NATO was before the second Gulf War, and where it is heading toward in its aftermath.

It would not be inaccurate to argue that NATO came about as the product of the strategic vision of the United States for the post-World War II era. Anticipating that the war would come to a close with the victory of the Allied powers, whereby the Soviet Union would occupy a significant portion of continental Europe, the United States wanted to initiate the necessary institutional frameworks that would enable it to maintain a foothold in Western Europe. As such, it was believed that the U.S. would achieve a "forward defense" capability against its primary antagonist, namely the Soviet Union, on the eve of the nuclear age. Hence, the estate value of Western Europe, neighboring the Soviet Union as well as its zone of influence, was extremely precious to the United States. Having the capability to strike the heartland of the Soviet Union from this near location, if need be, while keeping the continental U.S. still far from the reach of most Soviet military capabilities, was made possible thanks to the existence of the NATO alliance. The "delicate balance of terror" that was eventually achieved due to the mutual "second-strike capabilities" of both the U.S. and the Soviet Union ensured that a certain degree of stability could be maintained during the Cold War period.

With the collapse of the bipolar system and the disintegration of the Soviet Union, we must admit that continental Europe has lost its vitally significant strategic value for the U.S. NATO, which was the institutional framework born out of such a role, needed new roles to justify its existence after the collapse of the Warsaw Pact and the demise of the Soviet Union. That role was soon to be assumed by the Alliance as a result of the atrocities in the Balkans. The modalities of this new role, however, have come about as a result of painstaking deliberations between the Europeans and the Americans. At a time when an integrated Europe was poised to assert itself as a major power in world politics, Europe's continued dependence on the military capabilities of the U.S. was still a necessity for the aspiring European states, with Germany and France at the forefront.

Those in Europe who wanted to undermine the role of NATO in the European security and defense structures, or even to abolish it, failed first in Bosnia-Herzegovina, and then in Kosovo. The nature of disagreement at that point was more political, rather than legal or otherwise. At that time, there was not a serious debate on the legitimacy of NATO's (and thus the United States') military interventions in southeastern Europe. Both the Europeans as well as the Americans have agreed that, even though these were

\footnotetext{
Mustafa Kibaroglu is Associate Professor, Bilkent University.
} 
"out-of-area" type military operations, the so-called "emerging humanitarian law" would justify such interventions.

The terrorist attacks on September 11, 2001 have caused a dramatic change in the strategic vision of the United States. Up until that moment, the United States trusted its capabilities to retaliate in kind, and relied on the threat of the use of force to deter actual or potential aggressors. However, the September 11 attacks have shown that the U.S. could not wait until being attacked and then retaliate, because the damage that could be caused in such attacks could be catastrophic, as seen in New York and in Washington D.C. Moreover, those who would stage the attacks would probably have no specific physical location or infrastructure against which to retaliate. Therefore, these non-state actors, which relied on terror tactics, had to be prevented from implementing their plans. This could only be possible by preemption. Hence, the "preemptive strike" doctrine was adopted by the United States.

Even though the European members of the Transatlantic Alliance gave their full support to the U.S. in its military campaign against Afghanistan by enacting Article V of the Washington Treaty, substantial differences emerged soon after, when the U.S. wanted to expand the scope of its campaign by putting Iraq in line for military action. The reason behind the reluctance of some influential European members of NATO to give their support to the U.S. in its war against Iraq was two-fold. First, there was no clear link between the tragic events of September 11 that led the way to the Afghan campaign and the Saddam Hussein regime in Iraq. Second, there was this time serious disagreement between the Europeans and the Americans on the legitimacy of an intervention in Iraq. Hence, "in the absence of legitimacy" of an intervention, the leading members of the Alliance did not want to commit themselves, and thus refrained from giving their support to the U.S. There have been extended discussions on the legitimacy issue in the international arena, without making much reference to specific legal documents or articles of treaties.

The implications of such a loose debate became clear when Turkey wanted the Alliance to enact Article IV of the Washington Treaty with a view to paving the way to take the necessary measures in case Article $\mathrm{V}$ had to be put in operation. The same group of European countries, namely the Franco-German pact and a few others, has adamantly opposed Turkey's application. Such a treatment of Turkey heavily undermined the value of Turkey and of the Alliance as well. Although they did not specifically make the reference (at least to my knowledge) at any stage in their opposition, the Franco-German pact implicitly referred to Article I of the Washington Treaty, which suggests that the Allies should "refrain in their international relations from the threat or use of force in any manner inconsistent with the purposes of the United Nations."

It must be clear from the above statement that it would be inconceivable for the Franco-German pact to begin taking precautionary measures as envisaged by Article IV without their prior consent to the legitimacy of the U.S. involvement in Iraq in compliance with the basic principles of the UN. Hence, Article I of the Washington Treaty requires consistency with the UN's purposes for the involvement of any of the NATO allies in an international conflict. Having failed (in the view of the French and 
the Germans) to comply with the requirements of Article I, enacting Article IV and then Article V would be both unnecessary and impossible.

No matter what happened and why, the allies must look ahead and try to resolve their differences within the Alliance. NATO is both available and willing, and we should find ways to make the best use of its already existing and unmatched capabilities. The threat posed by non-state actors is huge and real. We have not yet, hopefully, experienced terrorism carried out with weapons of mass destruction, which is, unfortunately, not very unlikely. NATO can adapt itself to the requirements of the fight against terrorism. Those countries that believe they are immune to terrorism may soon be forced to realize that this cannot be the case for anybody. The only way to be safe from terror is by not being the target of terror. Those who have targeted the U.S., Britain, Turkey, and Spain may very well target other members of NATO in the future.

Therefore, while it is still not too late to unite NATO's capabilities against nonstate actors, peace-loving countries must do so at their earliest convenience and use NATO as the common platform to unite their will. NATO being a military organization that has fulfilled, to a great extent, the strategic vision of the U.S. since 1949 will survive as long as it fits into the new strategic vision of the U.S. for the twenty-first century. Otherwise, NATO may not have any additional value for the U.S. to justify maintaining it any further.

The civilized world has to defend its values against non-civilized intruders, namely the non-state actors that rely on terror as a tactic. It is hardly possible to determine who these actors are; where they are; how they communicate; what their capabilities are; and what their objectives are. No missile shields, no nuclear weapons, no large standing armies, no traditional components of sophisticated warfare capabilities of individual states can properly deal with the threat posed by these rootless, stateless groups. Intelligence is the most (if not the only) powerful and effective instrument that states need to defend their nations and their values. Since the threat is spread throughout the globe, the "battleground" should be the entire globe. Hence, worldwide cooperation is needed. But if there is one particular area where cooperation is most difficult, it is intelligence. NATO is the most appropriate venue where there has been a high level of sophistication of intelligence gathering as well as sharing. NATO's existing capabilities must therefore be made available to all peace-loving countries all over the world; NATO would also benefit from the intelligence that can come from these states. As such, NATO may very well assume a global role.

The continuation of NATO is highly important for the security of Turkey, but the relationship is not solely one-sided. Turkey can also contribute to a significant extent to the new role of NATO with its outstanding capabilities in collecting and developing intelligence. Turkey's close links in all regards with nations in its periphery, where the fight against terror is more heated, enable it to have timely access to strategic information about what is happening on the ground in these areas. Time will certainly prove the value of Turkey's contribution to the preservation of peace in the world. The civilized nations do not have the luxury to stay aloof from proposals to combine individual national capabilities against non-civilized administrations and terrorist groups. 